\title{
Peach Seedling Emergence and Growth in Response to Isothermal and Cycled Stratification Treatments Reveal Two Dormancy Components
}

\author{
Schuyler D. Seeley, ${ }^{1}$ Hamit Ayanoglu, ${ }^{2}$ and James W. Frisby ${ }^{3}$ \\ Plants, Soils, and Biometeorology, Utah State University, Logan, UT $84322-4820$
}

\begin{abstract}
Additional index words. cotyledons, endodormancy, Prunus persica, temperature response
Abstract. Dormant seeds of 'Johnson Elberta' peach [Prunus persica ( $\mathrm{L}$..) Batsch] were stratified at constant 2,6 , or $14{ }^{\circ} \mathrm{C}$ or cycled between 2 and $14^{\circ} \mathrm{C}$ in 12/12, 14/10, 16/8, 20/4, 22/2, or 23/1 h cycles. Emergence (measured every $3 \mathrm{~d}$ after planting) and normal seedling growth (measured after $49 \mathrm{~d}$ ) increased with longer stratification durations. Seeds stratified at $2^{\circ} \mathrm{C}$ had the most rapid emergence (only $28 \mathrm{~d}$ of stratification was required) but seedling growth was abnormal until $70 \mathrm{~d}$ of stratification. Isothermal stratification at $6^{\circ} \mathrm{C}$ resulted in normal seedlings after $56 \mathrm{~d}$ of stratification but quality and quantity of growth improved with stratification up to $70 \mathrm{~d}$. Seeds stratified at $14^{\circ} \mathrm{C}$ showed limited improvement in seedling emergence with time; seedling growth was poor and cotyledonary reserves were not used. Seedling growth after cycled stratification treatments gained normalcy faster than in the constant ${ }^{\circ} \mathrm{C}$ treatment. The $22 / 2$ and $20 / 4\left(2 / 14^{\circ} \mathrm{C}\right)$ cycles produced normal growth after $56 \mathrm{~d}$ of stratification that was comparable to the growth produced by the constant $6{ }^{\circ} \mathrm{C}$ treatment. Other cycles required $70 \mathrm{~d}$ or more for equivalent seedling growth. Improved seedling growth under cycled treatments could be due to developmental or growth promoting temperature effects of $14{ }^{\circ} \mathrm{C}$ during stratification or a combined effect of thermal accumulation and chilling occurring together after a minimal chilling requirement has been completed.
\end{abstract}

The nature of the deciduous fruit tree endodormancy mechanism is not known (Seeley, 1994). However, it is known that endodormancy release of buds and seeds of most deciduous fruit cultivars requires exposure to characteristic times at temperatures between -2 and 15 ${ }^{\circ} \mathrm{C}$ with an optimum of $\approx 5$ to $7^{\circ} \mathrm{C}$ (Erez and Lavee, 1971 ; Richardson et al., 1974; Secley and Damavandy, 1985). Apparently, several temperature-responsive systems are involved. One, the low (0) to 15 ${ }^{\circ} \mathrm{C}$ ) chilling response curve system, proceeds rapidly at a temperature of $\approx 0^{\circ} \mathrm{C}$ and decreases to zeroeffect at the compensation point of 0.15 ${ }^{\circ} \mathrm{C}$ (Abbott, 1955; Thevenot et al., 1983). Another, the development and growth curve system, begins just above the freczing point of water in plant tissues, slowly increases to $\approx 5^{\circ} \mathrm{C}$, and rises rapidly to a maximum equivalent to that of other cool season crops at $\approx 27^{\circ} \mathrm{C}$. The common area under the two curves results in the chilling response curve (Dennis, 1987; Seeley and Damavandy, 1985). Overlap of the two processes poses significant problems in their experimental investigation. Temperature manipulation may accelerate the endodormancy completion process.

Thermoperiodic cycling of rooted 'Redskin' and 'Redhaven' peach cuttings accelerated endodormancy release of lateral leaf buds (Erez et al., 1979). This chilling enhancement was verified with 'Redhaven' peach lateral leaf buds on trees cycled between low and moderate lemperature treatments (Erez and Couvillon, 1987). Thus, the endodormancy transition of lateral peach leaf buds can be accelerated with temperature cycling.

Secds are easier to use than buds in studies of endodormancy. They respond to temperature in a manner similar to buds of the same fruit cultivar (Chang and Werner, 1984; Pasternak-Orawiec and Powell, 1983a, 1983b; Westwood and Bjornstad, 1968). In recent

Received for publication 17 Nov. 1997. Accepted for publication 28 Apr. 1998. This report is based, in part, on research conducted and supported as part of SAFS Western Regional research project W-130. Utah Agricultural Experiment Station paper no. 6064. The cost of publishing this paper was defrayed in part by the payment of page charges. Under postal regulations, this paper therefore must be hereby marked advertisement solcly to indicate this fact.

Professor.

Graduate student

${ }^{3}$ Research technician. studies, peach seed germination and emergence were shown to be similar indicators of endodormancy release after various stratification treatments (Frisby and Seeley, 1993a).

High-temperalure treatments toward the end of endodormancy increase the germination rate of 'Golden Delicious' apple seeds (del RealLaborde, 1987). Seeds were stratified at constant $4^{\circ} \mathrm{C}$ with temperature intemuptions at 0 to $24^{\circ} \mathrm{C}\left(2^{\circ} \mathrm{C}\right.$ intervals) during each $1 / 4$ or $1 / 10$ of the total chilling time. Treatments with temperatures higher than the stratification range, given after $70 \%$ to $80 \%$ of the chilling requirement has been accumulated, caused the greatest reductions in germination. They also negated germination at other times. Treatments with cycled temperatures, 4 and $24^{\circ} \mathrm{C}$ on $12 / 12$ h cycles, resulted in significant $(40 \%$ to $50 \%$ ) reductions in germination versus constant $4{ }^{\circ} \mathrm{C}$ when given during the last three-fourths of the stratification time.

Guerriero et al. (1985) compared the effect of constant and cycled temperatures on endodormancy release of seeds of two apricot cultivars. Treatments were constant $5{ }^{\circ} \mathrm{C}$ and cyclic 5 and $15^{\circ} \mathrm{C}$ on $16 / 8 \mathrm{~h}$ cycles. They found that slightly fewer days were needed to get the same percentage budbreak at $5^{\circ} \mathrm{C}$ than with the cycled treatment. Yet, the cyclic chilling regime was more efficient in producing budbreak than the amount of time at $5{ }^{\circ} \mathrm{C}$ would suggest (budbreak with constant $5^{\circ} \mathrm{C}=67 \%$ break, budbreak with the same time at 5 plus $15^{\circ} \mathrm{C}$ in the cycle $=75 \%$ break).

Acceleration of seed endodormancy release would expedite studies into the nature of the endodormancy mechanism(s). Previous studies (Erez et al., 1979; Erez and Couvillon, 1987; Frisby and Seeley, 1993b) suggest that a combination of temperatures between $2{ }^{\circ} \mathrm{C}$ and a higher growth temperature might expedite seed endodormancy release.

Studies summarized here determined peach seed response to isothermal and thermoperiodic cycling treatments during stratification. Our objective was to determine whether stratification of peach sceds could be accelerated with cycled temperature treatments.

\section{Materials and Methods}

Secos. Sceds from the 1988 and 1989 seasons were used for experiments in 1989 and 1990, respectively. Peach pits were 
removed from mature fruit ('Johnson Elberta') grown at the Kaysville, Utah, Experiment Station and air dried. Seeds were removed from pits with a hand press and stored in plastic bags at room temperature. Only seeds with undamaged seed coats were used. Seeds were soaked in running $\left(7^{\circ} \mathrm{C}\right)$ water for $24 \mathrm{~h}$ at the beginning of each treatment. Replications of 10 seeds were placed on paper blotters (steel blue, $77 \times 77-\mathrm{mm}, 10-\mathrm{mm}$ triangle from each corner removed, Anchor Paper, St. Paul, Minn.) in plastic petridishes $(100 \times 9 \mathrm{~mm})$. Six mL of Captan (N-trichloromethylthio4-cyclohexene-1,2-dicarboximide, $0.3 \%$ a.i. w/v, $50 \mathrm{WP}$, Stauffer Chemical, Westport, Conn.) aqueous suspension was added to each petri dish. Petri dishes were sealed with Parafilm to prevent water loss, and covered with aluminum foil to exclude light.

Treatments. Stratilication temperature treatments were provided in boxes made of high-density extruded polystyrene foam $(5.0 \mathrm{~cm}$ thick, $60 \times 120 \times 120 \mathrm{~cm})$ located in a $0^{\circ} \mathrm{C}$ refrigerated room. Constant temperatures were maintained in these boxes with proportional temperature controllers (model 70-A; Nexis Custom Electronics, Brandon, V(.) that activated 20()-W light bulbs as heat sources. Small fans were placed over the light bulbs to increase convection and reduce the occurrence of cold or warm spots within the box. Temperature variations in the boxes were within $0.15^{\circ} \mathrm{C}$ of the desired temperature with a variation of $\pm 0.03{ }^{\circ} \mathrm{C}(95 \%$ confidence interval, repeated measures). Cycled temperature treatments were conducted in a similar chamber that consisted of two stacked boxes with the upper box temperature set at $14^{\circ} \mathrm{C}$ and the lower box at $2^{\circ} \mathrm{C}$. Additional cooling power was supplied in the 2 ${ }^{\circ} \mathrm{C}$ box with a $16 \mathrm{~m} \times 3 \mathrm{~mm}$ (i.d.) planar coiled, copper tube through which refrigerated ethylene glycol was circulated from an external circulator. Petri dishes containing seeds were placed on $10 \times 10$ $\mathrm{mm}$ hardware cloth supports $25 \mathrm{~mm}$ apart vertically inside $60-\mathrm{cm}$ $\times 203-\mathrm{mm}$-i.d. polyvinylchloride (PVC) tubes that were placed inside $120-\mathrm{cm} \times 254-\mathrm{mm}-\mathrm{i}$.d. PVC tubes extending vertically through both boxes. The ends of the smaller tubes (elevators) were equipped with polystyrene and rubber foam insulation to provide tight seals at the extremities of their travel into the 14 or $2{ }^{\circ} \mathrm{C}$ boxes. Portholes were cut in the sides of the tubes to allow ventilation and access to the petri dishes. The inside tube, the elevator, was moved from box to box with cables connected to micro-switched, reversible electric motors (model 2541; $6 \mathrm{rpm}, 10 \mathrm{~W}, 115 \mathrm{v}$, Hurst Motors, Princeton, Ind.) controlled by clock timers (model 2E213; 24 h, Dayton Electric Mfg. Co, Chicago). Four elevators were available with individual timers to control the time in each temperature chamber. Thermocouples (shielded from direct light) used to monitor temperatures inside the chambers were connected to an external datalogger (Campbell Scientific $21 \mathrm{X}$, Logan, Utah). Temperature variations in the boxes used in the cycling experiments were small, but larger than those in the single temperature boxes [setpoint temperature was within $0.25^{\circ} \mathrm{C}$ of the desired temperature and varied within $\pm 0.2{ }^{\circ} \mathrm{C}$ of setpoint temperature ( $95 \%$ confidence interval, repeated measures)].

Cycling temperatures were chosen from results of previous experiments with 'Johnson Elberta' peach seeds. Excellent emergence was obtained after $28 \mathrm{~d}$ of $2{ }^{\circ} \mathrm{C}$ stratification (Frisby and Seeley, 1993a), therefore $2{ }^{\circ} \mathrm{C}$ was chosen as the lower temperature. This temperature is below the growth threshold for cool season plants. We hypothesized that the $2{ }^{\circ} \mathrm{C}$ treatment would allow for the endodormancy transition to emergence with the shortest stratification time. The higher temperature, $14^{\circ} \mathrm{C}$, was chosen because it promotes normal growth of the chilled embryonic seedlings while supplying very little chilling and no negation (Abbott, 1955; Frisby and Seeley 1993b). Under this regime the seeds received the chilling requirement at $2^{\circ} \mathrm{C}$, a temperature that provided very little development and growth, and the promotive development and growth effects of a temperature $\left(14^{\circ} \mathrm{C}\right)$ that did not negate chilling. In this way, temperature confounding was minimized.

Seeds were stratified at constant 2,6 , or $14^{\circ} \mathrm{C}$ or cycled between 2 and $14{ }^{\circ} \mathrm{C}$ for $12 / 12,14 / 10,16 / 8$, or $18 / 6 \mathrm{~h}$ cycles in 1989 . The $6{ }^{\circ} \mathrm{C}$ chamber failed during the 1989 experiment. In 1990 , the same constant temperatures were used and the cycling treatments of 2 and $14{ }^{\circ} \mathrm{C}$ included $18 / 6,20 / 4,22 / 2$, and $23 / 1 \mathrm{~h}$ cycles. Seeds, which had been stored in plastic bags at room temperature, were prepared and stratified from 14 to $98 \mathrm{~d}$ (14-d intervals) in 1989 and from 14 to $70 \mathrm{~d}$ (14-d intervals) in 1990. Treatments were arranged so that all petri dishes were removed from stratification on the same calendar date. Germination (radicle length $>2 \mathrm{~mm}$ ) was recorded at the end of the stratification treatments. Seeds were planted $10 \mathrm{~mm}$ deep in flats $(10 \times 6)$ in a media of Sunshine mix no. 1, (Sungro, Bellingham, Wash.) using a completely randomized design.

Flats were placed in a greenhouse on 27 Oct., in both years, and seedling emergence was monitored at $3 \mathrm{~d}$ intervals starting $7 \mathrm{~d}$ after removal from stratification. Emergence was considered complete when the epicotyl appeared at the media surface. In 1989 the greenhouse temperature was set at $27 / 21^{\circ} \mathrm{C}$, day/night. Although light and photoperiod were not critical, sunlight was supplemented and photoperiod was extended to $16 \mathrm{~h}$ by use of 1000 -W highpressure sodium lamps that provided $800 \mu \mathrm{mol} \cdot \mathrm{m}^{-2} \cdot \mathrm{s}^{-2} \mathrm{PPF}$. In 1990 , the greenhouse temperature was isothermal at $21 \pm 3{ }^{\circ} \mathrm{C}$.

Seedlings were harvested after $49 \mathrm{~d}$ in the greenhouse. They were placed in plastic bags in a dark cooler $\left(0^{\circ} \mathrm{C}\right)$ until seedling parts (main stems, lateral stems, normal leaves, abnormal leaves, and cotyledons) could be separated and measured [number, sizes, and dry mass $\left.\left(70^{\circ} \mathrm{C}\right)\right]$.

A completely randomized factorial experimental design was used with seven (1989) or five (1990) stratification durations and seven temperature treatments in each experiment. Five replications were used per treatment

\section{Results and Discussion}

Germination during STRATIFICATION. No germination occurred until after $70 \mathrm{~d}$ of stratification. Germination increased from $21 \%$ to $44 \%$ between 84 and $98 \mathrm{~d}$ of stratification in the $18 / 6$ cycle treatment that had the highest germination percentages. Cycling promoted germination during chilling when compared with isothermal 2 and $14{ }^{\circ} \mathrm{C}$ treatments. We attributed the germination during stratification to heat accumulation after the chilling requirement was essentially completed $\left(1680 \mathrm{~h}\right.$ at $\left.2{ }^{\circ} \mathrm{C}\right)$. Seeds treated at $2{ }^{\circ} \mathrm{C}$ had $10 \%$ germination after $98 \mathrm{~d}$, suggesting that temperatures as low as $2{ }^{\circ} \mathrm{C}$ can cause radicle growth. The second experiment was conducted to conclude stratification before germination occurred (70 d).

EMERgenCE. All sources of variation (stratification duration, temperature, and forcing time) and their three-way interaction were significant for seedling emergence in both experiments (Fig. 1). In general, emergence increased with stratification time in all temperatures and temperature combinations including the continuous $14^{\circ} \mathrm{C}$ treatments.

Emergence was $>80 \%$ after $22 \mathrm{~d}$ of forcing with only $28 \mathrm{~d}$ of stratification at $2{ }^{\circ} \mathrm{C}$ in both experiments (Fig. $1 \mathrm{~A}$ and $\mathrm{F}$ ). All of the cycled treatments were equal to or less promotive of emergence than stratification at $2{ }^{\circ} \mathrm{C}$ at $28 \mathrm{~d}$, and, generally, were more promotive as the proportion of time at $2{ }^{\circ} \mathrm{C}$ increased (Fig. $1 \mathrm{~B}-\mathrm{E}$ and $\mathrm{G}-\mathrm{J}$ ). Emergence after $13 \mathrm{~d}$ of forcing after $70 \mathrm{~d}$ of stratifica- 
tion was greater in the $18 / 6$ cycle in 1989 (Fig. 1B) and in the 22/ 2 and 20/4 cycles (Fig. $1 \mathrm{H}$ and I) in 1990 than in the other treatments. The $18 / 6$ treatment resulted in the highest emergence percentages ( $50 \%$ at $84 \mathrm{~d}$ to $96 \%$ at $98 \mathrm{~d}$ ) after $7 \mathrm{~d}$ of forcing (Fig. 1B). Exposure to $14^{\circ} \mathrm{C}$ cycled temperatures during late stratification allowed development of shoot primordia during chilling or increased subsequent shoot elongation during early seedling growth. Emergence after $28 \mathrm{~d}$ of stratification was greater for the constant $2{ }^{\circ} \mathrm{C}$ than for constant $6^{\circ} \mathrm{C}$ for all forcing periods longer than 13 $\mathrm{d}$ in 1990 (no data for 1989 due to a chamber failure). The $6^{\circ} \mathrm{C}$ isothermal treatment $(1990$, Fig. 1 K) produced faster emergence than the $2{ }^{\circ} \mathrm{C}$ treatment after $70 \mathrm{~d}$ of stratification (Fig. 1F), probably due to thermal accumulation during chilling, but emergence after stratification at the two temperatures was not significantly different after $22 \mathrm{~d}$ of forcing, regardless of the duration.

Emergence was poor after stratification at $14{ }^{\circ} \mathrm{C}$ regardless of the duration with very limited emergence during the first $13 \mathrm{~d}$ of forcing ( Fig $1 \mathrm{~L}$ and $\mathrm{M}$ ). However, emergence after stratification at $14{ }^{\circ} \mathrm{C}$ increased to $25 \%$ during the next $9 \mathrm{~d}$ of forcing, and to $\approx 40 \%$ after $25 \mathrm{~d}$ of forcing, and then remained at that level (averages of two experiments). Final emergence (31 d of forcing) after $70 \mathrm{~d}(1989)$ and $98 \mathrm{~d}(1990)$ of stratification at $14{ }^{\circ} \mathrm{C}$ reached $38 \%$ to $40 \%$. The increase in emergence was sigmoidal and different for the two seed lots. Stratification for $56 \mathrm{~d}$ at $14{ }^{\circ} \mathrm{C}$ gave greater emergence percentages than stratification for $70 \mathrm{~d}$ in each experiment (Fig $1 \mathrm{~L}$ and $\mathrm{M}$ ). The highest emergence $(40 \%)$ was reached in the 1990 experiment in only $50 \mathrm{~d}$ compared with 98 $\mathrm{d}$ in the 1989 experiment. Thus, yearly seed lots varied in their response to $14^{\circ} \mathrm{C}$ stratification. Emergence at $14^{\circ} \mathrm{C}$ in these experiments was significant but not as great as previously reported (Frisby and Seeley, 1993a). The compensation point temperature (Abbott, 1955) for these seeds may be higher than $14{ }^{\circ} \mathrm{C}$.

These data confirm that processes leading to emergence (epicotyl development and elongation) occurred early in stratification at temperatures below the $5^{\circ} \mathrm{C}$ temperature threshold (Seeley and Damavandy, 1985). After emergence release following $28 \mathrm{~d}$ of stratification at $2{ }^{\circ} \mathrm{C}$, temperatures above the growth threshold during stratification contributed to shoot primordia development and subsequent shoot elongation. The constant $6{ }^{\circ} \mathrm{C}$ treatment supplied adequate temperature for concurrent stratification and shoot primordia development.

SEedLING GRowth. Normal seedling growth indices such as primary stem growth and normal leaf growth increased as chilling time increased (Fig. 2). The only cycling times that produced normal seedlings in a shorter time than those from isothermal $2^{\circ} \mathrm{C}(70 \mathrm{~d}$, Fig. $2 \mathrm{~A}$ and F) were the $22 / 2$ and $20 / 4$ treatments in the 1990 experiment (Fig. $2 \mathrm{H}$ and I). The latter two treatments produced normal seedlings with only $56 \mathrm{~d}$ of stratification. However, isothermal treatment at $6{ }^{\circ} \mathrm{C}$ produced equivalent growth at $56 \mathrm{~d}$ and much larger seedlings after $70 \mathrm{~d}$ (Fig. 2K) of stratification than in any other treatment.

Abnormal seedling growth indicesepinastic leaves, number of lateral stems, and cotyledon dry mass - decreased with longer stratification durations (Fig. 2). However, even when growth was good after 84 and $98 \mathrm{~d}$ of stratification some epinastic leaves were still present. This may have been due to the high-temperature conditions in the greenhouse during germination and emergence (Pollock, 1962) or to the absence of intermediate temperatures during stratification that may be required for certain foliar developmental processes.

Lateral stem growth (size and mass) increased initially and then decreased with continued stratification in treatments with 24,23 , and $22 \mathrm{~h}$ at $2{ }^{\circ} \mathrm{C}$ (Fig. $2 \mathrm{~F}-\mathrm{H}$ ), and in the constant $6{ }^{\circ} \mathrm{C}$ treatment (Fig. 2K). Stratification at a constant $2{ }^{\circ} \mathrm{C}$ resulted in increased lateral stem growth between 14 and $28 \mathrm{~d}$. Lateral stem growth then

Fig. 1. The three-way interaction between stratification duration, temperature, and forcing period on percent emergence of 'Johnson Elberta' peach seeds. Seeds were stratified isothermally at 2,6 , or $14^{\circ} \mathrm{C}$ in each experiment or cycled between 2 and $14^{\circ} \mathrm{C}$ for $12 / 12,14 / 10,16 / 8$, or $18 / 6 \mathrm{~h}$ in the 1989 experiment and $18 / 6,20 /$ $2,22 / 2$, or $23 / 1 \mathrm{~h}$ in the 1990 experiment. Stratification duration ranged from 14 to $98 \mathrm{~d}$ in the 1989 experiment and from 14 to $70 \mathrm{~d}$ in the 1990 experiment. D\&T $=$ the $\mathrm{LSD}_{0.05}$ bars for differences among duration and temperature combinations when forcing periods were fixed. FP = the LSD 0.05 bars for comparisons among forcing periods when temperature and duration were fixed. The continuous rectangle at $16 \mathrm{~d}$ is to facilitate comparisons.

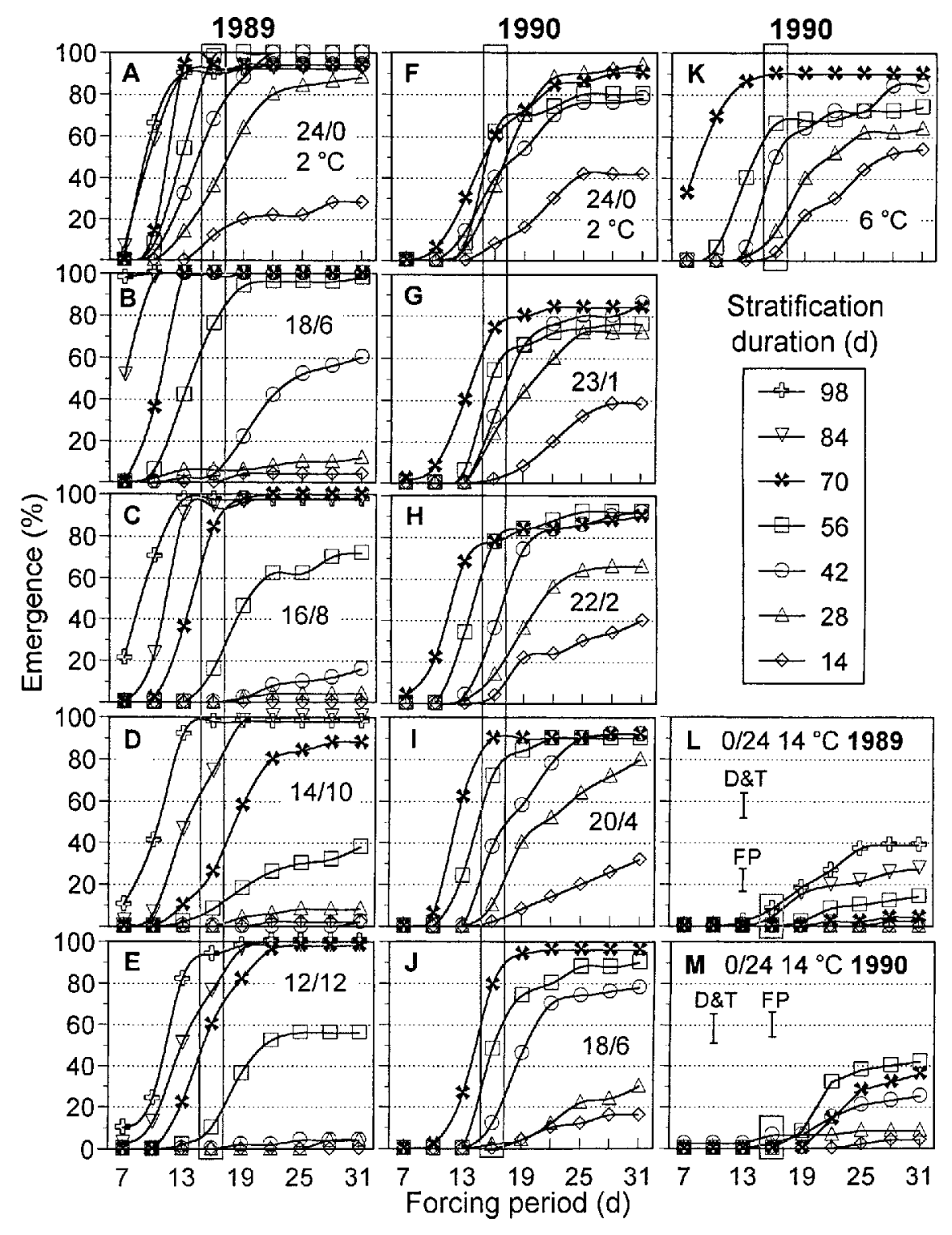


leveled off until $40 \mathrm{~d}$ and decreased to very small amounts after 70 d. Lateral stem mass decreased (20/4 cycled treatment) (Fig. 2 E and I) or changes were insignificant (absent) in cycled treatments with more time at $14^{\circ} \mathrm{C}$ (Fig. $2 \mathrm{D}-\mathrm{B}$ ). Significant lateral stem growth occurred only at 14 and $28 \mathrm{~d}$ of forcing after the $6{ }^{\circ} \mathrm{C}$ stratification treatment (Fig. 2K). Higher temperatures during stratification facilitate subsequent normal stem growth.

Cotyledon dry mass, presumably an indicator of the seedling's ability to mobilize reserves, decreased with stratification time except in seedlings stratified at constant $14^{\circ} \mathrm{C}$ (Fig. 2). Cotyledon dry masses of seedlings of seeds stratified at $14^{\circ} \mathrm{C}$ did not change

Fig. 2. 'Johnson Elherta' peach seedling transition from physiologically dwarfed to normal. Data are dry masses of normal leaves (NL), epinastic leaves (EL), main stems (S), lateral stems (LS), and cotyledons (C) of scedlings grown for $49 \mathrm{~d}$ in the greenhouse. Seeds were stratified from 28 to 70 (1990) or 28 to 98 (1989) d at isothermal $6^{\circ} \mathrm{C}$ or isothermal $2^{\circ} \mathrm{C}$ in each experiment, or cycled daily hetween 2 and $14^{\circ} \mathrm{C}$ for $12 / 12,14 / 10,16 / 8$, or $18 / 6 \mathrm{~h}$ in the 1989 experiment and $18 / 6,20 /$ $4,22 / 2$, or $23 / 1 \mathrm{~h}$ in the 1990 experiment. Ellipses indicate the shortest times in days for the production of normal appearing seedlings in each treatment. Bars are $\mathrm{LSD}_{0.05}$ for differences in seedling characteristics over time. Where sy mbols are not connected $\left(14^{\circ} \mathrm{C}\right.$ trcatments in 1989 and 1990) very few samples emerged $(<10 \%)$ and the data are nol trustworthy. or increased with stratification time (Fig. $2 \mathrm{~L}$ and $\mathrm{M}$ ), and were significantly greater than other treatments in the longest stratification durations of the two experiments.

Normal seedlings were produced after $56 \mathrm{~d}$ of stratification in the $22 / 2$ and $20 / 4$ cycles and at constant $6{ }^{\circ} \mathrm{C}$ treatments (Fig. $2 \mathrm{H}$, $\mathrm{I}$, and $\mathrm{K}$ ). Seventy days were required to produce normal seedlings in the constant $2{ }^{\circ} \mathrm{C}$ and cycled $23 / 1,18 / 6$, and $16 / 8$ treatments (Fig. $2 \mathrm{~A}-\mathrm{C}, \mathrm{F}, \mathrm{G}$, and J). Normal seedlings were produced only after $98 \mathrm{~d}$ in the $12 / 12$ and $14 / 10$ treatments (Fig. $2 \mathrm{D}$ and E). Therefore, limited exposure to higher temperatures or stratification at an intermediate temperature $\left(6^{\circ} \mathrm{C}\right)$ during stratification expedited production of normal seedlings.

Seeley and Frisby (1993b) reported that seedling growth was a poor indicator of the chilling process due to the occurrence of abnormal seedlings, especially for seeds chilled at $2{ }^{\circ} \mathrm{C}$. They postulated that a cycling treatment that would take advantage of the emergence response in the first 3 to 4 weeks time at $2{ }^{\circ} \mathrm{C}$ and a higher temperature would result in normal seedlings. Our results here indicate that is true. It may be possible to accelerate emergence and produce normal seedlings in a shorter time by stratifying peach seeds at constant $2^{\circ} \mathrm{C}$ for $28 \mathrm{~d}$ followed by an intermediate temperature $\left(6^{\circ} \mathrm{C}\right)$ or a higher cycled temperature $\left(7\right.$ to $\left.14^{\circ} \mathrm{C}\right)$ for several more weeks. However, the best higher temperature (perhaps the compensation point, probably above $14{ }^{\circ} \mathrm{C}$ for these seeds, Abbott, 1955) for cycling for stratifying these seeds remains unknown. For accurate modeling of endodormancy release of these seeds, determinations of the compensation point temperature, the optimum emergence chilling temperature, the optimum chilling temperature curve for removal of abnormal leaves and lateral stems, and the value of negating higher temperatures are required. Some improvements in seedling growth were noted with cycled temperature stratification treatments ( 2 and $14{ }^{\circ} \mathrm{C}$ ) but those improvements took as long or longer to get the desired results as isothermal treatment $\left(6^{\circ} \mathrm{C}\right)$. Our results confirm Guerriero's (Guerriero et al., 1985) in showing that some cycled treatments were more effective than the amount of time at $2{ }^{\circ} \mathrm{C}$ would suggest.

'Johnson Elberta' peach seeds developed the ability to emerge during the first $28 \mathrm{~d}[\approx 675 \mathrm{~h}$, or 490 chill units (Frisby and Seeley, 1993a; Seeley and Damavandy, 1985)] of stratification at $2{ }^{\circ} \mathrm{C}$, a temperature lower than the optimum for the entire stratification process. Subsequently, developmental changes in the transition from epinastic to normal leaves, from lateral to primary stems, and ability to unload cotyledons occurred. These later developmental changes occurred faster under higher constant $\left(6^{\circ} \mathrm{C}\right)$ or cycled temperature conditions with very short times ( 2 to $4 \mathrm{~h}$ ) in a 24 h cycle. Thus, the endodormant 'Johnson Elberta' peach seed transition can be separated into two components, the first being a low-temperature emergence-ability response and the second being the transition from physiologically dwarfed plants to normal growing seedlings. Survival potential is vested in a strategy that initiates root growth and establishment of a rosette plant (physi- 
ological dwarf) with the development of a substantial root system and reserve accumulation in the first year of growth in preparation for second year growth as an alternative to normal first year growth. Physiological dwarfs, those with epinastic leaves and lateral stems and shortened main stems, will return to normal during their second year if adequately chilled.

Growth and development after cycled stratification treatments were not as rapid or only marginally faster than after isothermal treatments. We conclude that endodormancy release in peach seed stratification is not accelerated by temperature cycling in the same way as it is in lateral leaf bud chilling (Erez et al., 1979; Erez and Couvillon, 1987). These cycling stratification treatments cannot accelerate peach seed stratification sufficiently to make a significant time difference in endodormancy studies.

\section{Literature Cited}

Abbott, D.L. 1955. Temperature and the dormancy of apple seeds. Report XIV Intl. Hort. Congr. 2A:746-753.

Chang, S. and D.J. Werner. 1984. Relationship of seed germination and respiration during stratification with cultivar chilling requirement in peach. J. Amer. Soc. Hort. Sci. 109:42-45.

del Real Laborde, J.I. 1987. Effect of temperature during stratification on rest completion of apple (Malus domestica) seeds. MS thesis. Utah State Univ., Logan.

Dennis, Ir., F.G. 1987. Two methods of studying rest: temperature alternation and genetic analysis. HortScience 22:820-824.

Erez, A. and S. Lavee. 1971. The effect of climatic conditions on dormancy development of peach buds. I. Temperature. J. Amer. Soc. Hort. Sci. 96:711-714.

Erez, A. and G.A. Couvillon. 1987. Characterization of the influence of moderate temperatures on rest completion in peach. J. Amer. Soc. Hort.
Sci. 112:677-680.

Erez, A., G.A. Couvillon, and C.H. Hendershott. 1979. Quantitative chilling enhancement and negation in peach buds by high temperatures in a daily cycle. J. Amer. Soc. Hort. Sci. 104:536-540.

Frisby, J.W. and S.D. Seeley. 1993a. Chilling of endodormant peach propagules. I. Seed germination and emergence. J. Amer. Soc. Hort. Sci. 118:248-252.

Frisby, J.W. and S.D. Seeley. 1993b. Chilling of endodormant peach propagules: V. Comparisons between seeds, seedlings, and cuttings. J. Amer. Soc. Hort. Sci. 118:269-273.

Guerriero, R., S.E.P. Indiogine, and G. Scalabrelli. 1985. Effect of stratification duration on seed germination of several peach line rootstocks. Acta Hort. 173:185-190.

Pasternak-Orawiec, G. and L.E. Powell. 1983a. Changes in abscisic acid and gibberellin during the stratification of low and high chilling apple seeds. HortScience 18:560 (Abstr.).

Pasternak-Orawiec, G. and L.E. Powell. 1983b. Chilling requirements for seeds of late-blooming apples. HortScience 18:561 (Abstr.).

Pollock, B.M. 1962. Temperature control of physiological dwarfing in peach seedlings. Plant Physiol. 37:190-197.

Richardson, E.A., S.D. Seeley, and D.R. Walker. 1974. A model for estimating the completion of rest for 'Redhaven' and 'Elberta' peach trees. HortScience 9:331-332.

Seeley, S. 1994. Dormancy-The black box. HortScience 29:1248.

Seeley, S.D. and H. Damavandy. 1985. Response of seed of seven deciduous fruits to stratification temperatures and implications for modeling. J. Amer. Soc. Hort. Sci. 110:726-729.

Thevenot, C., E.D. Perino, and D. Come. 1983. Influence of temperature on breaking of dormancy, germination sensu stricto and growth of apple embryo: Thermal optimum of these phenomena. Israel J. Bot. 32:139-145.

Westwood, M.N. and H.O. Bjornstad. 1968. Chilling requirements of dormant seeds of 14 pear species as related to their climatic adaptation. Proc. Amer. Soc. Hort. Sci. 92:141-149. 